\title{
PHYTOTOXICITY AND GROWTH OF COFFEE PLANTS AS A FUNCTION OF THE APPLICATION OF HERBICIDE 2,4-D
}

\author{
Giovani Belutti Voltolini ${ }^{1}$, Dalyse Toledo Castanheira ${ }^{2}$, Larissa Cocato da Silva ${ }^{3}$, \\ Ademilson de Oliveira Alecrim ${ }^{4}$, Tiago Teruel Rezende 5 , \\ João Paulo Rodrigues Alves Delfino Barbosa ${ }^{6}$, Rubens José Guimarães ${ }^{7}$
}

(Received: August 29, 2019; accepted: September 23, 2019)

\begin{abstract}
Weed control in coffee is of great importance for there is a great interference, standing out the competition for water, light and nutrients. Among the control methods, chemical control is highlighted as a function of its efficiency. However, the incorrect application of herbicides may imply the occurrence of drift, resulting in damage to coffee development due to phytotoxicity. In this context, the objective of this study was to evaluate the symptoms and phytotoxicity effects caused by the herbicide 2,4-D drift on the morphological, physiological and anatomical characteristics of coffee seedlings. The experiment was carried out in a greenhouse with 'Topázio MG1190' coffee seedlings (Coffea arabica L.), planted in 11-L pots. A randomized block design with four treatments and four replicates was used. The treatments were: $0 \% ; 10 \% ; 25 \%$ and $50 \%$ of the recommended commercial dose of 2,4-D (2.5 L.ha-1). Each plot consisted of three plants. The evaluations were performed at 74 days after implantation. Morphological, physiological, anatomical and phytotoxicity symptoms were evaluated as a function of the simulated herbicide drift. Coffee seedlings intoxicated by the herbicide 2,4-D presented hyponastic, chlorosis, shriveling and leaf anomalies. In the orthotropic branch, bending was observed in its extension, besides thickening in the collar region; in the plagiotropic branch, cracking was observed. Herbicide drift negatively affects the development of coffee plants. The coffee physiology was affected as a function of herbicide drift, but without damage to the leaf anatomy.
\end{abstract}

Index Terms: Coffea arabica, chemical control, damage, drift.

\section{INTRODUCTION}

Coffee is a crop of great national importance and, in this context Brazil stands out as the largest producer and exporter of this grain. Several factors interfere with coffee yield, among them climatic and management factors are of great importance. In management, weed control can be highlighted, since it is a practice that must be carried out in the crop to avoid competition and, consequently, damage to plant growth and development (LORENZI, 2014). Losses in agricultural crops by weed interference are estimated around $20-30 \%$ in Brazil (LORENZI, 2014). This interference occurs due to competition for water, light, $\mathrm{CO}_{2}$ and nutrients, which are frequently limited to the crop itself (RONCHI and SILVA, 2003; FIALHO et al., 2011; OLIVEIRA JR, 2011).

Among the control methods, chemical control is outstanding, due to its efficiency and yield. However, care must be taken with its application practices since, when applied incorrectly, the spray can reach the crop of interest, leading to coffee damage (LORENZI, 2014).
In this context, 2,4-dichlorophenoxyacetic acid $(2,4-\mathrm{D})$ is a herbicide classified as hormonal, of the phenoxyacetic group, the first selective herbicide successful in agriculture. |However, despite having a record for coffee cultivation and a widespread use in crops, 2,4-D can lead to coffee damage or even plant death. This is due to the fact that eudicotyledons do not metabolize synthetic auxins as rapidly as indoleacetic acid (IAA), natural to plants (RODRIGUES and ALMEIDA, 2018). On the other hand, monocotyledons are less sensitive to these synthetic auxins, since they inactivate them rapidly by conjugation. In addition, they also have receptor and auxinbinding proteins that bind to these synthetic auxins with lower affinity (TAIZ and ZEIGER, 2009).

Therefore, herbicide drift in the crops of interest may lead to phytotoxicity and, consequently, result in delays in plant development or even death (YAMASHITA et al., 2009; SILVA et al., 2017; CASTANHEIRA et al., 2019). In view of the above, was to evaluate the symptoms and phytotoxicity effects caused by the herbicide 2,4-D drift on the morphological, physiological and anatomical characteristics of coffee plants.

\footnotetext{
1,3,4,6Universidade Federal de Lavras/UFLA - Departamento de Agricultura/DAG - Cx. P. 3037 - 37.200-000 - Lavras - MG giovanibelutti77@hotmail.com, cocatolarissa@gmail.com, ademilsonagronomia@gmail.com, rubensjg@dag.ufla.br ${ }^{2}$ Universidade Federal de Viçosa/ UFV - Departamento de Fitotecnia/DFT - Avenida Peter Henry Rolfs, s/n Campus Universitário 36.570-900 - Viçosa - MG - dalysecastanheira@hotmail.com

${ }^{5}$ Universidade José do Rosário Vellano - Rodovia MG 179, km 0 - Campus Universitário 37.152-440 - Alfenas - MG - tiago.rezende@unifenas.br ${ }^{6}$ Universidade Federal de Lavras/UFLA - Departamento de Biologia - DBI/ Setor de Fisiologia Vegetal - 37.200-000 - Lavras - MG jp.barbosa@ufla.br
} 


\section{MATERIAL AND METHODS}

The experiment was carried out in a greenhouse from December 2017 to March 2018. For the simulation of intoxication, 'Topázio MG1190' coffee (Coffea arabica L.) seedlings were used in 11-L pots. A randomized block design with four replicates and four doses of the herbicide $2,4-\mathrm{D}$ was used: $0 \% ; 10 \% ; 25 \%$ and $50 \%$ of the recommended commercial dose $(2,5$ L.ha ${ }^{-1}$ ), applied directly on the coffee plants. Each plot consisted of three plants.

The application of the herbicide at different doses was carried out using a $\mathrm{CO}_{2}$ pressurized costal sprayer, with pressure of 45 pounds, and the spray bar was directed close to the top of the plants, with a spray volume of 300 L.ha' ${ }^{1}$. After the application, the plants remained in the greenhouse for 74 days, daily irrigated, aiming at the maintenance of field capacity. The management and cultural treatment were carried out as recommended by Matiello (2010).

Visual observation and imaging of the symptoms caused by the action of the herbicide were performed daily. The anatomical and physiological evaluations of the plants were performed at the end of the experiment. The following growth response variables were evaluated (morphological): plant height, measured in centimeters from the colon to the terminal bud of the orthotropic branch of plants; number of leaves; stem diameter, measured in milimeters at the height of the plant colon; number of plagiotropic branches; leaf area, in $\mathrm{cm}^{2}$, quantified by leaf discs (CUNHA et al., 2010); dry matter of leaves, plagiotropic branches, orthotropic branch, and root system, all in grams. Root length analysis, in centimeters, was also determined by the sum of the linear extension of each fragment of the root system, and mean root diameter, in milimeters, both using the imaging software Safira (JORGE and SILVA, 2010).

For the evaluation of leaf anatomy, leaves located between the second and third node of the plagiotropic branch of the plants were collected from the branch apex at the end of the experiment. Leaves with symptoms were not collected since, at the date of collection, they were not in the standard position, according to leaf sampling methodology for anatomical studies (SEGATTO et al., 2004). After field collection, in the laboratory, the paradermic and transverse sections were performed. Those paradermic were obtained using the universal instant adhesive (cyanoacrylate ester) method (SEGATTO et al., 2004). In order to obtain the cross sections, the plant material underwent dehydration in an ethylic series, and was then immersed in methacrylate (methodology according to the manufacturer) and sectioned with $0.8 \mu \mathrm{m}$ thickness using a rotary microtome. Subsequently, these were stained with toluidine blue (O'BRIEN; FEDER; MCCULLY, 1964) and the blades were assembled using Entelan ${ }^{\circledR}$ as a medium. The slides of both sections (paradermic and transverse) were observed and photographed under an optical microscope coupled to a digital camera. The images obtained were analyzed in the UTHSCSA-Imagetool software and then the stomatal characteristics, leaf tissues and vascular bundles were evaluated. For stomatal characterization, the following characteristics were evaluated: stomatal number; polar diameter of the stomata and equatorial diameter of stomata. With this data, stomatal density, number of stomata per $\mathrm{mm}^{2}$ and the polar diameter/equatorial diameter stomatal ratio, which is highly correlated with stomatal functionality (SILVA et al., 2014), were calculated. To evaluate leaf tissues, the following were measured: epidermal thickness of the adaxial surface; thickness of the palisade parenchyma; thickness of the spongy parenchyma; epidermal thickness of the abaxial surface and thickness of the mesophyll. In the evaluation of vascular bundles, the following parameters were measured: thickness of the phloem region; diameter of xylem vessels and number of xylem vessels.

For the physiological analyses, a portable infrared gas analysis system (LICOR - 6400XT) was used to evaluate the net photosynthetic rate (A - $\mu \mathrm{mol} \mathrm{CO} \mathrm{C}^{-2} \mathrm{~s}^{-1}$ ), stomatal conductance (gs $\left.\mathrm{mol} \mathrm{H}_{2} \mathrm{O} \mathrm{m}^{-2} \mathrm{~s}^{-1}\right)$, and transpiration rate $(\mathrm{E}-\mathrm{mmol}$ $\mathrm{m}^{-2} \mathrm{~s}^{-1}$ ). Water use efficiency (EUA - $\mu \mathrm{mol} \mathrm{CO}_{2}$ $\mathrm{mmol}^{-1} \mathrm{H}_{2} \mathrm{O}$ ), calculated by the $\mathrm{A} / \mathrm{E}$ ratio (YAN et al., 2015), was also evaluated. The evaluations were performed between 9 and 11 o'clock in the morning under artificial light $\left(1000 \mathrm{mmol} \mathrm{m}^{-2} \mathrm{~s}^{-1}\right)$, using fully expanded leaves of plagiotropic branches of plants.

For data analysis, the SISVAR statistical software was used, through the F test (FERREIRA, 2011). The statistical software $R$, version 3.2.3 (R DEVELOPMENT CORE TEAM, 2016) was used to adjust the linear models to the data obtained. For the estimation of the model parameters and to perform the analysis of variance, the functions aov and summary, respectively, of the stats 
library, were used. For the response variables that presented differences $(\mathrm{p}<0.05)$, the regression models that were able to explain the maximum of the observed variation of the response variable as a function of herbicide doses, were adjusted.

\section{RESULTS AND DISCUSSION}

The symptoms caused by the action of the herbicide were observed in several parts of the plant, due to its systemicity, being present in leaves, orthotropic branch, plagiotropic branches, plant collar and roots.

The plants exposed to the herbicide 2,4D produced characteristic symptoms of auxin mimics, presenting phytotoxicity due to the abnormal increase in auxin, leading to accelerated and disordered cell division and stretching in plants (TAIZ and ZEIGER, 2009).

In the leaves, the appearance of symptoms was observed from the second day after the application of the herbicide, and chlorosis, shriveling and hyponastic response were observed. Above all, these disorders are caused by the action on cellulase, an enzyme derived from the ethylene route, which acts on the loosening of these tissues (BELO et al., 2011) (Figure 1).

In the orthotropic branch, hyponastic response was observed, that is, the bending in certain parts of the branch, caused by the excess of auxin in the stem segment. In the same way, disturbances were also verified in the plagiotropic branches. However, they showed cracking, reason of the accelerated growth and consequent collapse of tissue cells. In the collar area of the plant, with $50 \%$ of the commercial dose of the herbicide, thickening was observed, which may be associated with an early secondary growth; this intense cellular multiplication also caused callus formation (Figure 2).

In addition to these typical symptoms observed, when 2,4-D was used, it was also possible to characterize a new symptom caused by the dysfunction of plant tissues. In this context, some leaf segments close to the apex region of the plagiotropic branch, with $10 \%$ of the commercial dose of the herbicide, presented an abnormal shape, differing from the morphology of the coffee plant, which, by classification, are opposite, and were cast in the emission of the same pair of leaves (Figure 3).

Given the above, the originality of these symptoms makes it necessary to have a broader discussion aimed at clarifying the possible causes of plant metabolism. Thus, it is possible to try to correlate the existence of these leaf anomalies to the Kn1 gene, which acts directly on foliar morphogenesis (LINCOLN, et al., 1994). In particular, auxin/cytokinin imbalance in plant organisms interferes with the expression of this gene, so that changes in leaf shape occur due to the differentiation in the expression (SACHS, 2000).

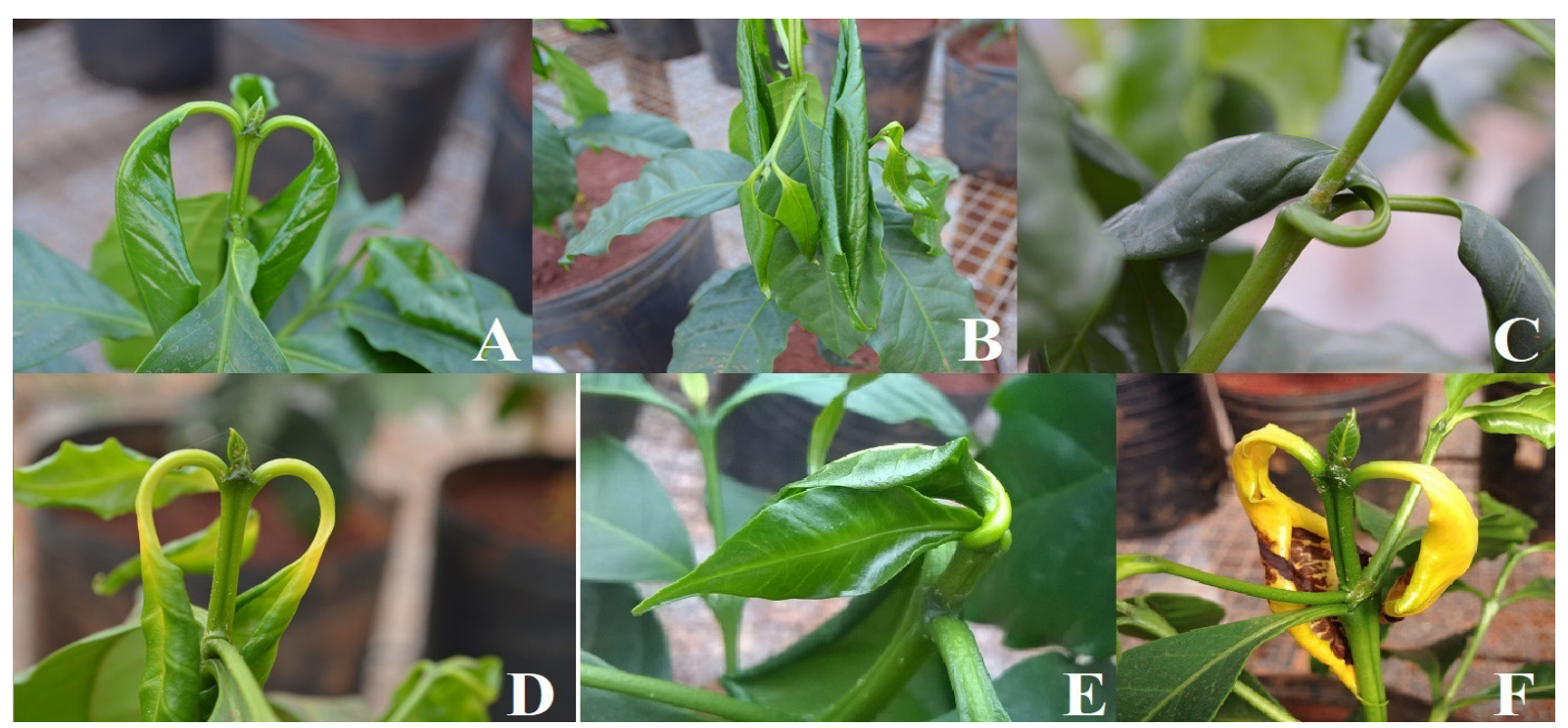

FIGURE 1 - Symptoms of 2,4-D drift intoxication in young coffee plants. (A) and (B) hyponastic response in young leaves; (C) hyponastic response in older leaves; (D) light hyponastic response chlorosis; (E) hyponastic response in apical leaves and (F) hyponastic response with marked chlorosis and necrosis in the leaves of plants treated with the herbicide. 


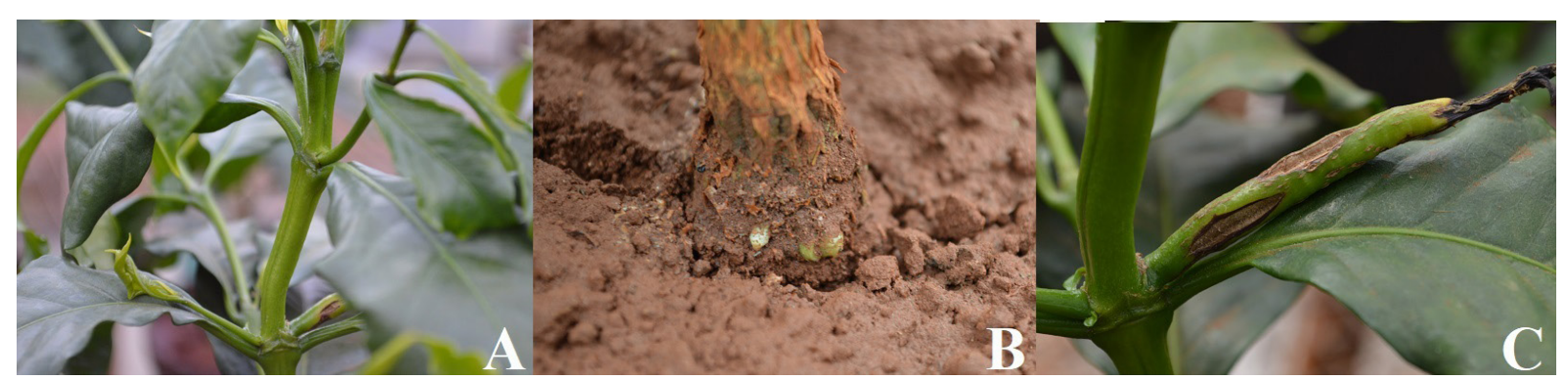

FIGURE 2 - Bending of the orthotropic branch (A), thickening in the collar region (B) and cracking in the plagiotropic branch (C). Source: The authors (2018)

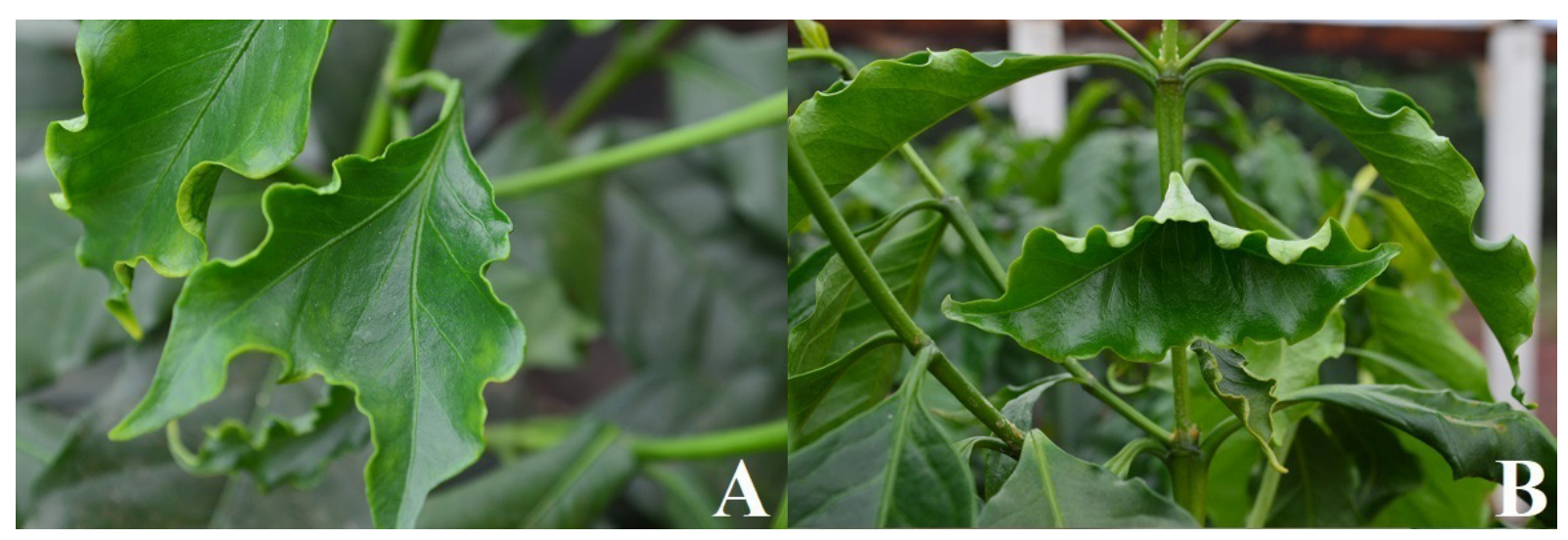

FIGURE 3 - Symptoms of 2,4-D drift intoxication in young coffee plants. (A) junction of two leaves of the apical meristem in open format; (B) junction of two leaves of the apical meristem in closed format.

For the anatomical characteristics: number of stomata, polar and equatorial diameter of stomata, stomatal functionality, stomatal density, abaxial epidermis thickness, palisade parenchyma thickness, lacunar parenchyma thickness, adaxial epidermal thickness, leaf mesophyll thickness, number of xylem vessels, average thickness of xylem vessels and phloem thickness had no significant effect as a function of the doses of the herbicide. Likewise, there was no significant effect on root mean diameter.

For growth characteristics: height, stem diameter, number and weight of leaves, leaf area, number and weight of plagiotropic branches, weight of the orthotropic branch, root dry matter and total root length, there was a significant effect among treatments; in the same way for the physiological characteristics: photosynthetic rate, stomatal conductance, internal carbon and water use efficiency (Figure 4 and Figure 5).

Regarding the characteristics studied, plant height showed a quadratic decrease as the doses of the herbicide 2,4-D were increased (Figure 4 ). The dose 1.10 L.ha ${ }^{-1}$ yielded the lowest height $(38.47 \mathrm{~cm})$; this decrease may be associated with the way auxin acts on plant metabolism, being the precursor of ethylene (HANSEN \& GROSSMANN, 2000), which acts to inhibit plant growth, by stomatal closure and consequent reduction in enzymatic activity, photosynthetic and cell division, thus justifying the results found in this study.

As for stem diameter, this characteristic followed a cubic tendency in response to the treatments and, initially, a decrease in the values was observed, with subsequent increase in these values (Figure 4). Above all, this downward trend is related to the action of 2,4-D as a herbicide, acting in the inhibition of plant growth and development. On the other hand, the subsequent increase in diameter is justified by the action of 2,4-D as a hormone, providing an early secondary growth, inducing thickening (GROSSMANN, 2000; GROSSMANN, 2010).

A decrease in quadratic order was observed for the number of leaves, leaf dry matter and leaf area, as the doses of the herbicide 2,4-D increased, as there were smaller increases in these characteristics. 

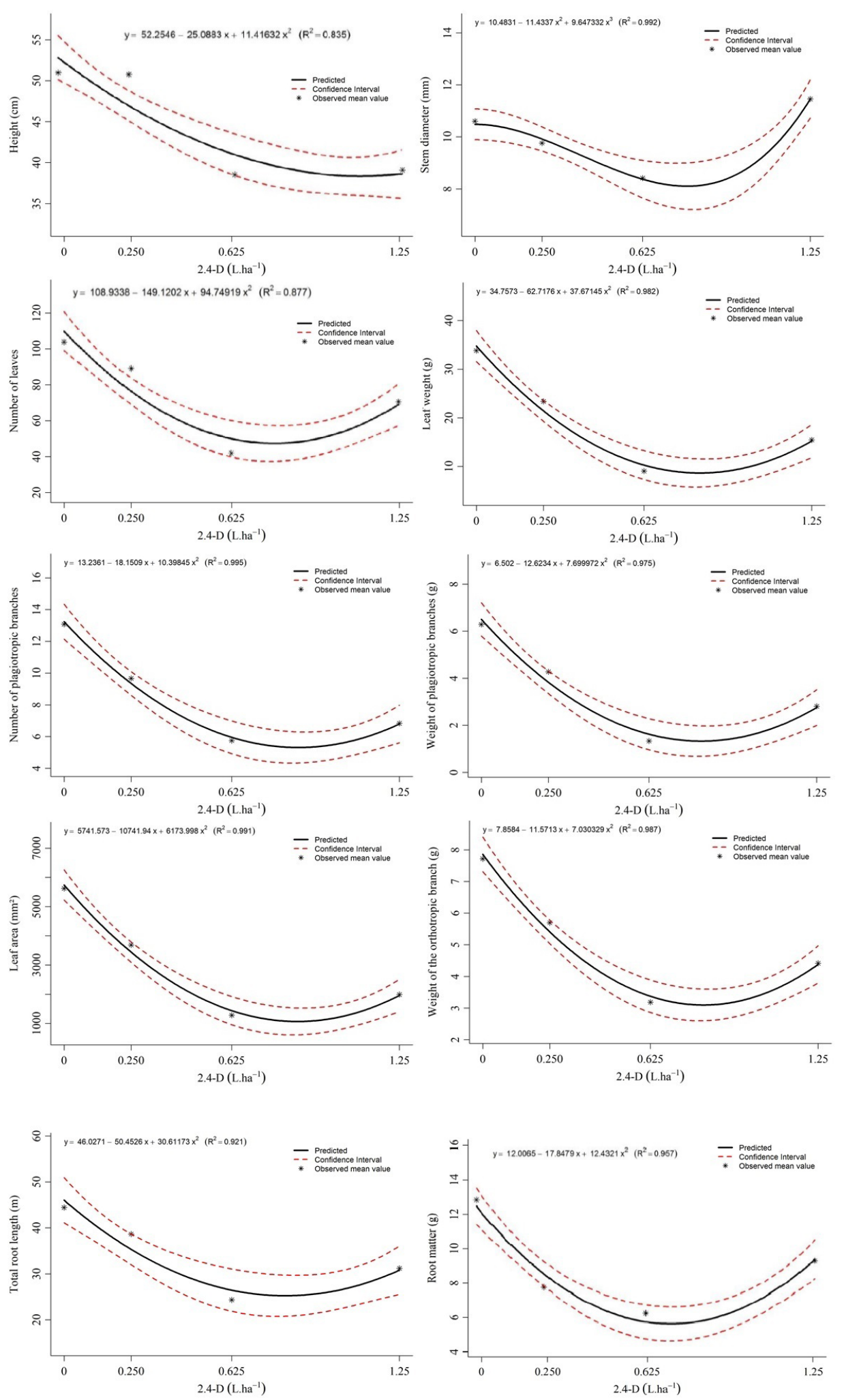

FIGURE 4 - Predicted values and confidence intervals (95\%) for height $(\mathrm{cm})$, stem diameter ( $\mathrm{mm})$, number and weight of leaves $(\mathrm{g})$, leaf area $\left(\mathrm{mm}^{2}\right)$, number and weight of plagiotropic branches $(\mathrm{g})$, weight of the orthotropic branch $(\mathrm{g})$, root matter $(\mathrm{g})$ and total root length as a function of 2,4 - D doses. 

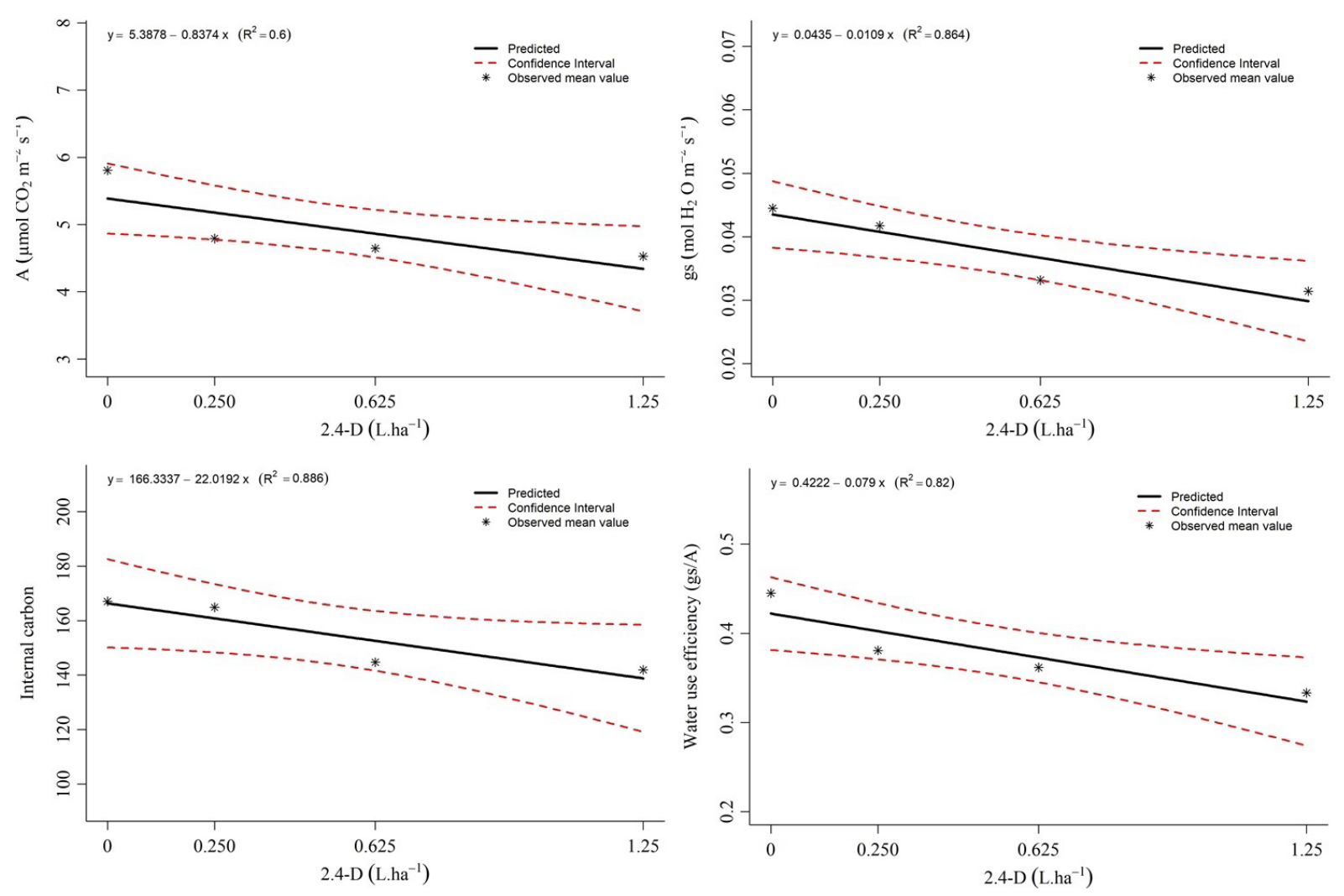

FIGURE 5 - Predicted values and confidence intervals (95\%) for photosynthetic rate $\left(\mathrm{A}-\mu \mathrm{mol} \mathrm{CO}_{2} \mathrm{~m}^{-2} \mathrm{~s}^{-1}\right)$, stomatal conductance $\left(\mathrm{gs}-\mathrm{mol} \mathrm{H}_{2} \mathrm{O} \mathrm{m}^{-2} \mathrm{~s}^{-1}\right)$, internal carbon $\left(-\mathrm{mmol} \mathrm{m} \mathrm{m}^{-2} \mathrm{~s}^{-1}\right)$ and water use efficiency (EUA - $\mu \mathrm{mol}$ $\mathrm{CO}_{2} \mathrm{mmol}^{-1} \mathrm{H}_{2} \mathrm{O}$ ) as a function of $2,4-\mathrm{D}$ doses.

The dose 0.78 L.ha $^{-1}$ reflected in the lowest number of leaves, with 50.26 leaves and, for leaf weight, the dose $0.83 \mathrm{~L}^{-\mathrm{ha}^{-1}}$ resulted in the lowest observed weight, $8.65 \mathrm{~g}$. The lowest leaf area, $1069.18 \mathrm{~mm}^{2}$, was observed at the dose 0.87 L.ha' ${ }^{-1}$. It is possible to explain these results due to the action of auxin, inducing the biosynthesis of ethylene which, consequently, as a senescence hormone, causes, in addition to other dysfunctions, leaf fall.

For the characteristics number and weight of plagiotropic branches, and weight of the orthotropic branch, a quadratic decrease was also observed with the increase in doses of the herbicide. The lowest number of plagiotropic branches, 5.31, was observed at the dose of 0.87 L.ha ${ }^{-1}$. The dose 0.82 L.ha $^{-1}$ reflected in the lowest weight of plagiotropic branches and weight of orthotropic branches, respectively, 1.33 and 3.10 g. This may have occurred since, as well as for height, these characteristics are also influenced by the action of ethylene, inducing stomatal closure, therefore causing inhibition of plant growth and development.
For the roots, the characteristic dry matter

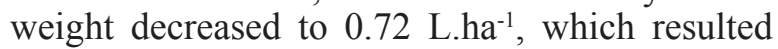
in the lowest root dry matter, with 5.6 grams. In addition to weight, the total root length was also influenced by the herbicide, following a quadratic trend, so that lower growth was observed as the herbicide doses increased. This can be explained by the great sensitivity of the coffee root system when exposed to high doses of auxin, inhibiting their growth and development (TAIZ and ZEIGER, 2009).

For the physiological characteristics photosynthesis, stomatal conductance, internal carbon and water use efficiency, it was observed that, with the increase in 2,4-D doses applied, there was a quadratic decrease in these characteristics of the plants, so that, as the doses were increased, there was a quantitative reduction in the parameters (Figure 5). This may have occurred due to increased ethylene production that acts on leaf senescence, thus inhibiting the photosynthetic activity of the plants. Grossmann (2010) also observed a reduction in photosynthetic activity as a function of excess auxin in plants. 


\section{CONCLUSIONS}

2,4-D drift impaired the growth of coffee plants.

The phytotoxicity symptoms observed in the leaves were chlorosis, shriveling and hyponastic response, and could evolve into necrosis. The presence of leaf anomalies was also observed.

The symptoms observed in the orthotropic branch were hyponastic response and thickening in the collar region. In plagiotropic branches, abnormal growth was observed, with tissue cell collapse (cracking).

Coffee physiology was affected as a function of herbicide drift, but without damage to the leaf anatomy.

\section{ACKNOWLEDGEMENTS}

The authors would like to thank CAPES, FAPEMIG, CNPq and EMBRAPA for the support in the conduction of this study.

\section{REFERENCES}

BELO A. F., et al. Photosynthetic activity of plants cultivated in soil contaminated with picloram. Planta Daninha, Viçosa, v.29, n.1, p.885-892, 2011.

CASTANHEIRA, D. T., et al. Growth, anatomy and physiology of coffee plants intoxicated by the herbicide glyphosate. Coffee Science, Lavras, v. 14, n. 1, p. 76 82, jan./mar. 2019.

CUNHA, J. L. X. L., et al. Comparação de métodos de área foliar em Chrysobalanus icaco L. Agropecuária Científica no Semiárido, Patos, v. 6, n. 3, p. 22-27, jul./set. 2010.

FERREIRA, D. F. Sisvar: a computer statistical analysis system. Ciência e Agrotecnologia, Lavras, v. 35, n. 6, p. 1039-1042, 2011.

FIALHO, C.M.T., et al. Interferência de plantas daninhas sobre o crescimento inicial de Coffea arábica. Planta Daninha, v. 29, n. 1, p. 137-147, 2011.

GROSSMANN, K. Mode of action of auxinic herbicides: a new ending to a long, drawn out story. Trends Plant Sci., v. 5, n. 12, p. 506-8, 2000.

GROSSMANN, K. Auxin herbicides: current status of mechanism and mode of action. Pest Management Science, v.66, n.2, p.113120, 2010.

HANSEN, H.; GROSSMANN, K. Auxin-induced ethylene triggers abscisic acid biosynthesis and growth inhibition. Plant Physiology, v. 124, n. 3, p. 1437$1448,2000$.

JORGE, L. A. C.; SILVA, D. J. C. B. SAFIRA: Manual de utilização. São Carlos: Embrapa CPDIA, 2010. 29p.

LINCOLN C.; et al. A Knotted-like homeobox gene in Arabidopsis is expressed in the vegetative meristem and dramatically alters morphology when overexpressed in transgenic plants leaf. Plant Cell, v.6, p.1859-1876, 1994.

LORENZI, H. Manual de Identificação e controle de plantas daninhas. $7^{\mathrm{a}}$ Ed. Nova Odessa - SP. Instituto Plantarum, 2014. 384p.

MATIELlO, J. B. et al. Cultura de Café no Brasil: manual de recomendações. Rio de Janeiro: MAPA/ PROCAFE, 2010. 542 p.

O'BRIEN, T. P.; FEDER, N.; MCCULLY, Mi E. Polychromatic staining of plant cell walls by toluidine blue O. Protoplasma, USA, v. 59, n. 2, p. 368-373, 1964.

OLIVEIRA JR, R. S. de. Introdução ao controle químico. Biologia e Manejo de plantas daninhas, p. 125-140, 2011.

R DEVELOPMENT CORE TEAM. R: a language and environment for statisti- cal computing. Vienna: R Foundation for Statistical Computing, 2016. Disponível em: <http://www.R-project.org>. Acesso em: 12 jan. 2016.

RODRIGUES, B. N.; ALMEIDA, F. S. de. Guia de herbicidas. 7. ed. Londrina: Grafmarke, 2018. 697

RONCHI, C.P.; SILVA. A.A. Tolerância de mudas de café a herbicidas aplicados em pós-emergência. Planta Daninha, Viçosa-MG, v. 21, n. 3, p.421-426, 2003.

SACHS, T. Integrating cellular and organismic aspects of vascular differentiation. Plant and Cell Physiology, Oxford, v. 41, p. 649-656, 2000.

SEGATTO, F. B.; et al. Técnica para o estudo da anatomia da epiderme foliar de batata. Ciência Rural, v.34, n.5, p.1597-1601, 2004.

SILVA, H., et al. Relationships between leaf anatomy, morphology, and water use efficiency in Aloe vera (L) Burm f. as a function of water availability. Revista chilena de história natural, Santiago, v. 87, n. 1, p. 13, 2014. 
SILVA, L. G., et al. Sintomas de fitotoxicidade e crescimento de mudas de café submetidas aos herbicidas inibidores da PROTOX. Coffee Science, Lavras, v.12, n.3, 2017

TAIZ, L.; ZEIGER, E. Fisiologia vegetal. In: Fisiologia vegetal. Artmed, p. 819, 2009.
YAMASHITA, O.M. et al. Influência do glyphosate e 2,4D sobre o desenvolvimento inicial de espécies florestais. Scientia Forestalis, v.37, n.84, p.359-366, 2009.

YAN, J., et al. High photosynthetic rate and water use efficiency of Miscanthus lutarioriparius characterize an energy crop in the semiarid temperate region. Gcb Bioenergy v. 7, n. 2, p. 207-218, 2015. 